\title{
Social Entrepreneurship, a Key Driver to Improve the Quality of Life: The Case of TOMS Company
}

http://doi.org/10.21272/bel.4(3).65-72.2020

Loredana Nicoleta Zainea, ORCID: https://orcid.org/0000-0002-7743-8217

PhD Student, Doctoral School of Management, The Bucharest University of Economic Studies, Bucharest, Romania

Sorin-George Toma, ORCID: https://orcid.org/0000-0001-9116-7751

$\mathrm{PhD}$, Professor, Faculty of Administration and Business, University of Bucharest, Bucharest, Romania

Cătălin Grădinaru, ORCID: https://orcid.org/0000-0002-3095-6316

$\mathrm{PhD}$, Lecturer, Faculty of Administration and Business, University of Bucharest, Bucharest, Romania

Ștefan Catană, ORCID: https://orcid.org/0000-0003-3013-3923

$\mathrm{PhD}$, Faculty of Administration and Business, University of Bucharest, Bucharest, Romania

\begin{abstract}
Due to rapid evolution of new technologies and the accelerated economic and social change, many organizations have realized in recent years that in order to survive in this turbulent and competitive global environment it is necessary to take into account the needs and expectations of their stakeholders, as well as to make the labour relationships more flexible and to adopt a socially responsible behaviour. Social enterprises may be the solution as they represent a business model adapted to the 21 st century, which through their activity create a balance between economic, financial, cultural, social and environmental needs. In fact, last decades have witnessed the emergence and development of concepts such as social economy and enterprise, social entrepreneurship. As a driver of innovation, job creation and economic growth, social entrepreneurship can and should contribute to economic well-being and social progress. On this line, it is worth to emphasize that the activities of social entrepreneurs may have an appreciable impact on the quality of life of people around the world. Also, social entrepreneurship represents a complex and multidimensional concept that has constituted a topic of great significance for numerous researchers in the past decades. The paper aims to define the concepts of social entrepreneurship and quality of life, and to illustrate their relationship in the case of TOMS company. The descriptive and quantitative research method used by the authors was based on secondary data found in the electronic databases, international journals and corporate reports. The paper contributes to a better understanding of the two concepts, namely social entrepreneurship and quality of life. Also, it shows that they are two related concepts as the first one has a positive impact on the second one through various actions, such as ensuring the basic material conditions, increasing the level of education, or improving the health system.
\end{abstract}

Keywords: Social Entrepreneurship, Quality of Life, Entrepreneurship, TOMS Company.

JEL Classification: M290, I310, O1.

This work is licensed under a Creative Commons Attribution 4.0 International License

Cite as: Zainea, N. L., Toma, S.G., Grădinaru, C., Catană, S. (2020). Social Entrepreneurship, a Key Driver to Improve the Quality of Life: The Case of TOMS Company. Business Ethics and Leadership, 4(3), 65-72. http://doi.org/10.21272/bel.4(3).65-72.2020.

(C) The Authors, 2020. This article is published with open access at Sumy State University.

\section{Introduction}

Currently, the living standard of human beings is influenced, on the one hand, by the increase of social costs caused by the aging population, people migration, and the higher share of inactive people, and, on the other hand, by the globalization phenomenon, respectively the interconnection between countries, regions or cultures and the connecting levers represented by the political, economic or social systems which are permanently changing. It is imperative to update the existing economic and social models or to develop new ones, that 
consider the social cohesion as a source of collective prosperity, that ensures an equitable economic growth. It builds on the realities of the communities and/or societies in which it is achieved. Social enterprises may be the solution as they represent a business model adapted to the 21st century, which creates a balance between economic, financial, cultural, social and environmental needs through their activity. In fact, last decades have witnessed the emergence and development of concepts such as social economy, social enterprise, and social entrepreneurship. As drivers of innovation, job creation and economic growth, social entrepreneurship and social enterprises, irrespective of their size, can and should contribute to economic well-being and social progress (Hoek, 2018). On this line, it is worth emphasizing that social entrepreneurs' activities may have an appreciable impact on the quality of life of people around the world (e.g., the widespread of the initiatives of Muhammad Yunus, the founder of Grameen Bank) (Kumar Jain, 2009). However, social entrepreneurship initiatives must consider the territory, history, culture and values of local community members. Starting from the fact that the role of any enterprises is essential within an economic system (Santos, 2012), a wide range of public policies have been implemented aimed at stimulating and developing entrepreneurship in general (Álvarez et al., 2012), and social entrepreneurship, in particular. The success of these policies is based on various factors such as the involvement of all stakeholders, an efficient way of using the financial instruments and a thorough collection and interpretation of the national and international statistics data.

In the case of social entrepreneurship, a significant body of literature has been developed in the last decades to highlight its positive impact on people's quality of life (Chell, 2007; Dacin et al., 2011). As a practice, social entrepreneurship creates economic and social value and, therefore, focuses on attaining social objectives (Nicholls, 2009; Pathak \& Muralidharan, 2018). Starting from this topic of major interest, existing both in the business literature and environment, the paper intends to address the following research question: Is there a link between social entrepreneurship and people's quality of life at the societal level? The paper aims to define the concepts of social entrepreneurship and quality of life and illustrate their relationship in the case of TOMS company. The structure of the article is as follows: the literature review is presented in the second part. The third part shows the research methodology, and the fourth part deals with the study case of the TOMS company. The paper ends with conclusions.

\section{Literature Review}

Social entrepreneurship. The concept of entrepreneurship appeared more than 200 years ago, and derives from the French 'entreprendre', which means 'to undertake'. Jean-Baptiste Say (1924), one of the first French writers who studied this concept, stated that the entrepreneur relocates economic resources from lower productivity to an area of higher productivity. Thus, entrepreneurship identifies and mobilizes resources from an inferior level of productivity to a superior one (Toma et al., 2014). As a relatively young field of research, social entrepreneurship has become part of the business lexicon since the turn of the century and details "the work and structures of community, voluntary, and public organizations and private firms working to solve social issues" (Phillips et al., 2015: 442). Consequently, a social entrepreneur is a person who creates and runs a for-profit or not organization and focuses on the innovative nature of its activity through the introduction of new ideas, methodologies, and manufacturing systems that are revolutionizing the field of activity, etc. (Kramer, 2005).

Although various opinions have been formulated regarding this subject, there is no unanimously accepted definition in the literature. However, social entrepreneurship may be defined as:

$>$ "a process involving the innovative use and combination of resources to pursue opportunities to catalyze social change and/or address social needs" (Mair \& Marti, 2004: 3);

$>$ "an innovative, social value-creating activity that can occur within or across the non-profit, business, or government sectors" (Austin et al., 2006: 2);

$>$ a concept "having the following three components: (1) identifying a stable but inherently unjust equilibrium that causes the exclusion, marginalization, or suffering of a segment of humanity that lacks the financial means or political clout to achieve any transformative benefit on its own; (2) identifying an opportunity in this unjust equilibrium, developing a social value proposition, and bringing to bear inspiration, creativity, direct action, courage, and fortitude, thereby challenging the stable state's hegemony; and (3) forging a new, stable equilibrium that releases trapped potential or alleviates the suffering of the targeted group, and through imitation and the creation of a stable ecosystem around the new equilibrium ensuring a better future for the targeted group and even society at large" (Martin \& Osberg, 2007: 35);

$>$ a concept that "encompasses the activities and processes undertaken to discover, define and exploit opportunities in order to enhance social wealth by creating new ventures or innovatively managing existing organizations" (Zahra et al., 2009: 522); 
"entrepreneurship that aims to provide innovative solutions to unsolved social problems" (OECD, 2010: 188);

"market-oriented initiatives that are innovatively pursuing social aims" (Huybrechts \& Nicholls, 2012: 39).

The above-presented definitions reveal several characteristics of social entrepreneurship. Firstly, it represents a complex and multidimensional concept that has constituted a topic of great significance for numerous researchers in the past decades (Kannampuzha \& Hockerts, 2019). Secondly, social entrepreneurship is an innovative activity of general interest that implies collective participation, carried out not only in the non-profit but also in the business or governmental sectors, whose purpose is to create social value, to promote social cohesion, and to meet the social needs of vulnerable groups within certain communities by providing them goods or services. In this respect, it comprises numerous types of activities as follows: "enterprising individuals devoted to making a difference; social purpose business ventures dedicated to adding for-profit motivations to the non-profit sector; new types of philanthropists supporting venture capital-like 'investment' portfolios; and non-profit organizations that are reinventing themselves by drawing on lessons learned from the business world" (Mair et al., 2006: 1). Thirdly, it acts as a catalyst for social change, and social entrepreneurs do not expect a direct monetary benefit from their social ventures (Barberá-Tomás, et al., 2019). Fourthly, social and cultural resources play a vital role in social entrepreneurship actions (Azmat et al., 2015). Fifthly, social entrepreneurship differs from traditional entrepreneurship (Beugre, 2017) because it seeks to transform profit into social capital to sustain the socio-economic development of society and/or community and, thus, increase the quality of life.

Quality of life. On its turn, the concept of quality of life emerged after World War II and was initially limited to the possession of essential goods such as clothes, food, or cars. Other terms, such as well-being and life satisfaction, were used interchangeably. Today's concept has to be seen through the relationship between the individual and the society, regarding the degree of trust in institutions, on the one hand, and on the other hand, through the quality of the public services that society provides. However, various factors, both external (e.g., economic resources, political system, health system, etc.) and internal (e.g., temperament, personality, motivations), influence the quality of life and determine the concrete circumstances of individual experience (Owczarek, 2010; Precupețu et al., 2018). According to the Organisation for Economic Co-operation and Development (OECD, 2020), 11 indicators have been taken into account for measuring the quality of life as follows: housing, income, jobs, community, education, environment, civic engagement, health, life satisfaction, safety, and work-life balance. Also, the Gross Domestic Product (GDP) per capita is a traditional indicator used to measure the population's living standard, which refers to income, consumption, and material living conditions of individuals. There are several definitions of the concept in the literature. Although there is no consensus about its meaning, quality of life may be defined as:

$>$ "a state of wellbeing which is a composite of two components: 1) the ability to perform everyday activities which reflects physical psychological, and social well-being and 2) patient satisfaction with levels of functioning and the control of disease and/or treatment-related symptoms" (Gotay \& Moore, 1992: 12);

$>$ "as a person's sense of wellbeing that stems from satisfaction or dissatisfaction with the areas of life that are important to him/her" (Ferrans \& Powers, 1992: 29);

$>$ "the individuals' perception of their position in life in the context of the culture and value systems in which they live, and in relation to their goals, expectations, standards and concerns" (WHOQOL Group, 1998: 551);

$>$ "a subjective, multidimensional experience of wellbeing that is culturally constructed as individuals seeks safety and security, a sense of integrity and meaning in life, and a sense of belonging in one's social network" (Kagawa-Singer et al., 2010: 59);

$>$ "a concept that involves those aspects of quality of life or function, which is influenced by health status and is based on dimensions (i.e., physical, psychological, and social aspects), which can be measured" (BenitoLeón et al., 2011: 676)";

$>$ "an individuals' perception of their position in life in the context of the culture and value systems in which they live and in relation to their goals, expectations, standards and concerns" (World Health Organization, 2020: 1).

The above definitions reveal several characteristics of quality of life. Firstly, it represents an umbrella term and covers multiple meanings as it has widespread use in different fields (e.g., sociology, economics, medicine). Secondly, quality of life "includes the full range of factors that make life worth living, including those that are not traded in markets and not captured by monetary measures" (Stiglitz et al., 2009: 63). In other words, it encompasses all factors that influence the individual's well-being. Thirdly, quality of life expresses the socio-economic performance of a society at a given time. Fourthly, this multidimensional concept captures both the positive and negative aspects of life (IESE Insight, 2013) and highlights the relationship between the individual and society in terms of personal objectives and expectations about the existing values, principles, 
and norms. The relationship between social entrepreneurship and quality of life has become a topic of interest for researchers in recent decades. In general, entrepreneurship and social entrepreneurship are considered to have a beneficial impact on society (Steyaert \& Hjorth, 2006; Kaufmann, 2009; Rey-Martí et al., 2016). Social entrepreneurship contributes to a better quality of life of people by combining resources to address diverse social needs, through its socially-oriented purpose and mission, through its innovativeness, proactiveness and altruistic dimensions, by engaging the problem-solving skills of individuals and organizations to find innovative solutions for social challenges etc. (Morris \& Lewis, 1991; Seelos \& Mair, 2005; Tan et al., 2005; Dees, 2007; Ratten \& Welpe, 2011; McMullen \& Warnick, 2016; Zahra \& Wright, 2016).

\section{Research Methodology}

The authors used a descriptive and quantitative research method as it describes the main characteristics of the phenomenon studied to attain the aims of the paper. In this respect, many secondary data were collected to review the literature. The needed information was gathered through desk research from various sources, such as books and articles found in electronic databases (e.g., Sage Journals, Google Scholar, Springer, Emerald Insight), international journals (e.g., Journal of Business Ethics, Social Enterprise Journal, Journal of World Business, Academy of Management Journal), and corporate reports. The data were carefully selected and grouped into categories. Then, the data were analyzed, correlated, and synthesized. Finally, the authors composed the article.

\section{Results}

Based on the literature review, the authors showed a relationship between social entrepreneurship and quality of life. On the one hand, social entrepreneurship initiatives improve people's quality of life. On the other hand, it stimulates the emergence and development of social entrepreneurship. TOMS was founded in 2006 by Blake Mycoskie, who, during his trip to Argentina, identified a social problem, namely the lack of footwear for needy children. Therefore, he decided to set up TOMS Shoes, whose main objective is to help children in need through the "One for one" program: a pair of shoes bought ensures another pair of shoes donated to a poor child. The program is available worldwide, and new jobs have been created in those communities aiming to produce footwear locally. Starting from this program, in its 13 years of activity, the TOMS company positively impacted 96.5 million lives (Figure 1). While society is constantly changing and the community issues are increasingly and become more complex, its mission has remained the same, namely "use business to improve lives" (TOMS Company, 2006). In other words, its mission is to create socio-economic benefits for both stakeholders and society at a global level. The company adopted a strategy in which the innovative and creative spirit can be found at all levels in its daily activity.

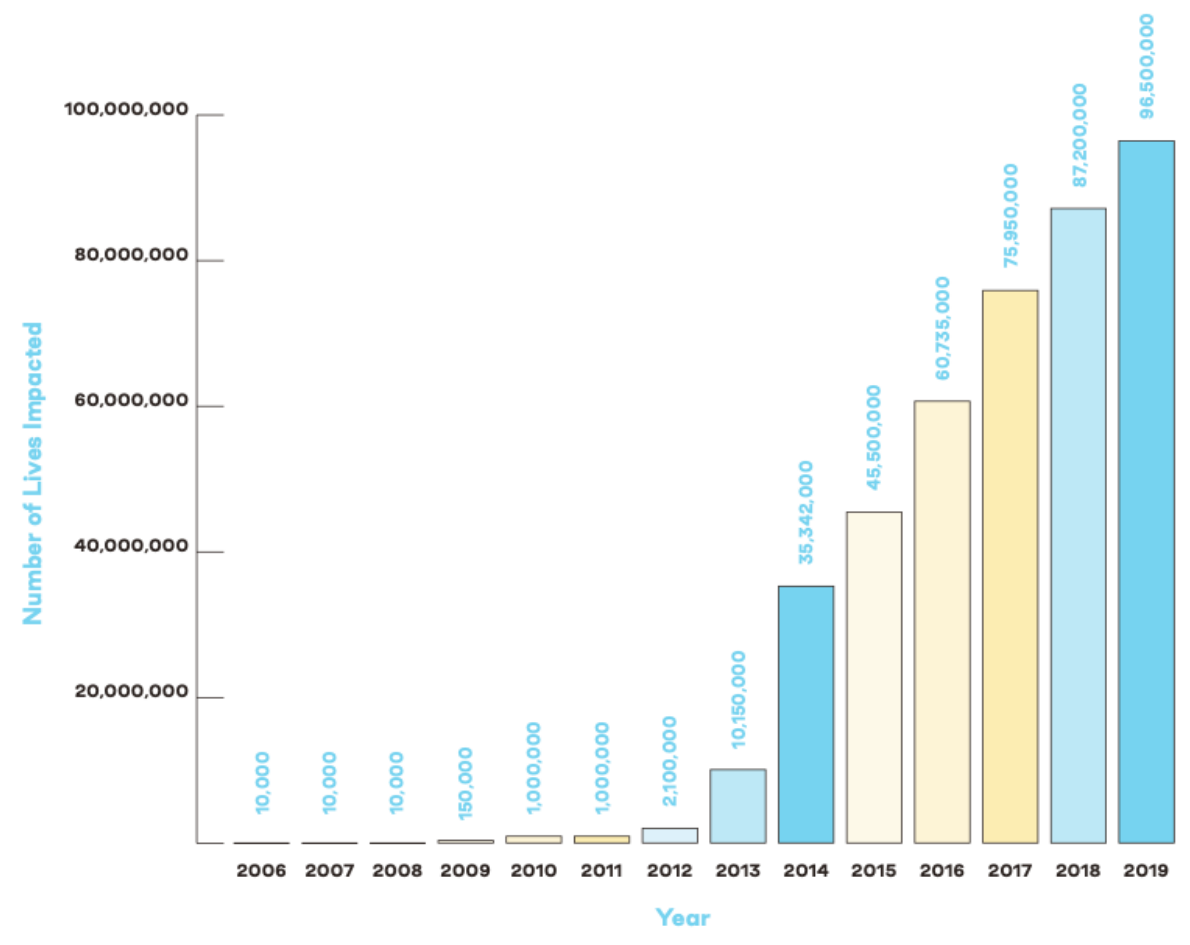

Source: TOMS Company, 2019

Figure 1. Lives impacted by TOMS' programs 
The company has set strategic objectives such as reduced inequalities, gender equality, decent work and economic growth, quality education, no poverty, good health, and well-being to accomplish the mission (TOMS Company, 2019). These objectives are integrated into the document entitled „Transforming our world: the 2030 Agenda for Sustainable Development", adopted in 2015 by all United Nations Member States, whose guidelines are oriented towards ensuring the peace and prosperity of peoples and planet, both now and in the future. The company selects its partners from non-governmental organizations and social enterprises, based on well-established criteria and qualifications, offering them the opportunity to participate in the existing programs to achieve these objectives. Their activity is monitored and evaluated based on reports, and the results express the degree of efficiency of the resources used. In 2018, TOMS became a Certified B Corporation following an assessment by the B Labs Independent Standards Advisory Council. This certification is forprofit companies that use business as a force for good (TOMS Company, 2019). The real impact of TOMS strategies consists in the fact that through its programs, the company offers hope, independence, health and numerous opportunities to those in need. TOMS run various socio-economic programs in various fields, such as Shoes program, Clean water program.

Shoes program. This program was born out of the desire to help people from multiple communities who have various risks of infections or other foot diseases, given that the fact over 1.5 billion people (24\% of the world's population) have a soil-transmitted infection. The report results of the Giving partners team highlighted the fact that this program has three types of benefits, as follows:

It ensures a basic protection of the feet against infections or other diseases (as a result of the program implementation, there was a decrease of over $60 \%$ foot-related diseases in communities at risk).

It facilitates the access to education of people in need, because the shoes are a mandatory condition of the school's dress code, on the one hand, and on the other hand, their cost does not affect the family budget anymore.

It creates a feeling of well-being and increases self-esteem.

Through the 167 Giving Partners of the program, 95 million pairs of shoes have been donated in 82 countries and 38 US states until 2019. The goal set for 2020 is to exceed the threshold of 100 million pairs of shoes donated. It can be stated that the implementation of this program has had positive effects on community members, as it has significantly increased the presence in schools, minimized the discrimination rate between pupils and students, and reduced the number of cases of foot infections.

Water program. The main goal of this program is to ensure the necessary drinking water to cover the daily basic needs, given the fact that a person needs at least 20 litres of water for drinking, washing and eating. The research showed that more than 785 million people do not have access to basic drinking water (World Health Organization, 2019). The program is carried out through Giving partners, who have extensive experience in drinking water quality, hygiene and sanitation. TOMS provide funding for WaterAid America and Water for People. Through the 3 Giving Partners, whose activity takes place in North America, South America, SubSaharan Africa, South Asia and Southeast Asia, the access to drinking water was ensured for 722.000 weeks (1 week=140 litres). In essence, TOMS has had many positive contributions, such as poverty reduction, increasing the quality of life by ensuring basic needs for safe drinking water, improving the hygiene conditions, and modernizing the sewerage systems. TOMS can be considered a responsible company, which faces complex challenges in its daily activity and tries to increase the quality of life in the communities in which it operates, by allocating a third of the annual net profit to a giving fund managed by TOMS Giving Team. The TOMS company is continually looking for new solutions to improve collaboration with its partners and create customer loyalty, seeking that each initiative will have a significant impact on individuals' and communities' well-being. Also, for its employees, the desire to have a positive impact at the society level represents the motivation to work with passion, efficiency, and personal contribution to fulfilling the organizational objectives (TOMS Company, 2006).

\section{Conclusions}

Social entrepreneurship uses market-based methods and techniques for solving society's and/or community's problems. It represents a key driver for improving the quality of life of people and communities, considering the economic and social accelerated changes, as well as the survival of companies in a turbulent and competitive global environment. The disadvantaged people's quality of life is often affected due to their defective material and financial resources, which can have either a positive impact on their lives when they are turned into a state of well-being or a negative effect when they are discriminated against they feel insecure. 
The paper contributes to a better understanding of the two concepts: social entrepreneurship and quality of life. Also, it shows that social entrepreneurship and quality of life are two related concepts as the first one has a positive impact on the second one through various actions, such as ensuring the primary material conditions, creating jobs for disadvantaged people, increasing the level of education, improving the health system, environmental protection, etc.

From a practical point of view, the TOMS business model can be replicated by other companies by disseminating its good practices, which must be done through various sources, to have a large addressability area. Firstly, one dissemination method is through modern communication instruments, especially in the online environment, which enables quick access, real-time updating of information, and transparency. The second method is to organize training, seminars, and other actions with specific themes to develop an organizational culture based on social responsibility values and principles because direct interaction between the speakers and the target audience creates opportunities for face-to-face debates and the participants may be potential social entrepreneurs. Simultaneously, inviting decision-makers who have been directly involved in such actions is beneficial, due to their power of example and experience, which are inspirations sources and successful role models for participants.

Thirdly, acceptable practices can be promoted through opinion leaders involved in community life because they gain the community members' trust. Fourthly, publications (such as impact reports) are also a powerful communication tool through their visual content, which has a significant impact on the knowledge transfer's potential beneficiaries. It can be said that the TOMS strategy has beneficial effects, materialized in increasing the confidence for both investors and employees, by protecting and maximizing the company's good-will, adopting a socially responsible behavior within their organization, reducing expenses, and losses by using resources efficiently. Further research may explore the influence of quality of life on social entrepreneurship, namely that various elements of quality of life can stimulate or discourage social entrepreneurship initiatives.

Author Contributions. Conceptualization, Loredana Nicoleta Zainea; data curation, Sorin-George Toma; formal analysis, Loredana Nicoleta Zainea; investigation, Loredana Nicoleta Zainea and Sorin-George Toma; methodology, Sorin-George Toma, Catalin Gradinaru and Stefan Catana; project administration, Loredana Nicoleta Zainea; resources, Sorin-George Toma; software, Loredana Nicoleta Zainea; supervision, Loredana Nicoleta Zainea and Sorin-George Toma; validation, Loredana Nicoleta Zainea and Sorin-George Toma; visualization, Loredana Nicoleta Zainea and Sorin-George Toma; writing - original draft, Loredana Nicoleta Zainea; writing - review \& editing, Sorin-George Toma, Catalin Gradinaru and Stefan Catana. All authors have read and agreed to the published version of the manuscript.

Funding. This research was funded solely by the authors.

\section{References}

1. Álvarez, C., Noguera, M., \& Urbano, D. (2012). Condicionantes del entorno y emprendimiento femenino : une studio cuantitativo en Espana [Environment determinants and female entrepreneurship: a quantitative study in Spain]. Economía Industrial, 383, 43-52. Available at: https://www.mincotur.gob.es/Publicaciones/Publicacionesperiodicas/EconomiaIndustrial/RevistaEconomi aIndustrial/383/Claudia\%20Alvarez.pdf.

2. Austin, J., Stevenson, H. \& Wei-Skillern, J. (2006). Social and commercial entrepreneurship: Same, different, or both? Entrepreneurship Theory and Practice, 30(1), 1-22. https://doi.org/10.1111/j.15406520.2006.00107.x.

3. Azmat, F., Ferdous, A.S., \& Couchman, P. (2015). Understanting the dynamics between social entrepreneurship and inclusive growth in subsistence marketplaces. Journal of Public Policy and Marketing, 34(2), 252-271. https://doi.org/10.1509/jppm.14.150.

4. Barberá-Tomás, D., Castelló, I., de Bakker, F. G., \& Zietsma, C. (2019). Energizing through visuals: How social entrepreneurs use emotion-symbolic work for social change. Academy of Management Journal, 62(6), 1789-1817. https://doi.org/10.5465/amj.2017.1488.

5. Benito-León, J., Rivera-Navarro, J., Guerrero, A.L., De Las Heras, Benito-León, J., Rivera-Navarro, J., Guerrero, A.L., De Las Heras, V., Balseiro, J., Rodríguez, E., \& Martínez-Martín, P. (2011). The CAREQOL-MS was a useful instrument to measure caregiver quality of life in multiple sclerosis. Journal of Clinical Epidemiology, 64(6), 675-686. DOI:10.1016/j.jclinepi.2010.08.003.

6. Beugre, C. (2017). Social Entrepreneurship: Managing the Creation of Social Value. New York: Routledge. 330p. Available at: https://www.routledge.com/Social-Entrepreneurship-Managing-the-Creation-of$\underline{\text { Social-Value/Beugre/p/book/9780415817370. }}$. 
7. Chell, E. (2007). Social enterprise and entrepreneurship: Towards a convergent theory of the entrepreneurial process. International Small Business Journal, 25(5), 5-26. https://doi.org/10.1177/0266242607071779.

8. Dacin, M.T., Dacin, P. A., \& Tracey, P. (2011). Social entrepreneurship: A critique and future directions. Organization Science, 22(5), 1203-1213. http://dx.doi.org/10.1287/orsc.1100.0620.

9. Dees, J.G. (2007). Taking social entrepreneurship seriously. Society, 44(3), 24-31. DOI:10.1007/BF02819936.

10.Ferrans, C. E., \& Powers, M.J. (1992). Psychometric assessment of the quality of life index. Research in Nursing \& Health, 15, 29-38. https://doi.org/10.1002/nur.4770150106.

11.Gotay, C. C., \& Moore T. D. (1992). Assessing quality of life in head and neck cancer. Quality of Life Research, 1(1), 5-17. DOI: 10.1007/BF00435431.

12.Hoek, M. (2018). The Trillion Dollar Shift: Achieving the Sustainable Development Goals. London: Routledge. 432p. Available at: https://www.routledge.com/The-Trillion-DollarShift/Hoek/p/book/9780815364313.

13.Huybrechts, B., \& Nicholls, A. (2012). Social Entrepreneurship: Definitions, Drivers and Challenges. In: C. K. Volkmann, K.O. Tokarski, K. Ernst (eds.) (2012). Social Entrepreneurship and Social Business: An Introduction and Discussion with Case Studies. Springer: Wiesbaden. 31-48. ISBN 978-3-8349-7093-0. Available at: https://www.springer.com/gp/book/9783834927293.

14.IESE Insight (2013). Quality Of Life: Everyone Wants It, But What Is It? [Online] Available at: https://www.forbes.com/sites/iese/2013/09/04/quality-of-life-everyone-wants-it-but-what-isit/\#5db607db635d [Accessed 5 July 2020].

15.Kagawa-Singer, M., Padilla, G. V., \& Ashing-Giwa, K. (2010). Health-related quality of life and culture. Seminars in Oncology Nursing, 26, 59-67. DOI:10.1016/j.soncn.2009.11.008.

16.Kannampuzha, M. \& Hockerts, K. (2019). Organizational social entrepreneurship: Scale development and validation. Social Enterprise Journal, 15(3), 290-319. https://doi.org/10.1108/SEJ-06-2018-0047.

17.Kaufmann, H.R. (2009). The contribution of entrepreneurship to society. Entrepreneurtship and Small Business, 7(1), 59-73. DOI: 10.1504/IJESB.2009.021609.

18.Kramer, M.R. (2005). Measuring Innovation: evaluation in the field of social entrepreneurship. [Online] Available www.skollfoundation.org/media/skoll_docs/Measuring20lnnovation20(Skoll20and20FSG20Report).pdf [Accessed 25 July 2020].

19.Kumar Jain, T. (2009). Discovering social entrepreneurship. Asia-Pacific Business Review, V(1), 21-34. https://doi.org/10.1177/097324700900500103.

20.Mair, J., \& Marti, I. (2004). Social entrepreneurship research: A source of explanation, prediction, and delight. IESE Working Paper, 546, 1-21. [Online] Available at: file:///C:/Users/Admin/AppData/Local/Temp/Social_entrepreneurship_What_are_we_talking_about_pdf. [Accessed 1 August 2020].

21.Mair, J., Robinson, J., \& Hockerts, K. (eds.) (2006). Social Entrepreneurship. London: Palgrave Macmillan. 280p. Available at: https://www.palgrave.com/gp/book/9781403996640.

22.Martin, R.L. \& Osberg, S. (2007). Social entrepreneurship: The case for definition. Stanford Social Innovation Review, Spring 2007, 28-39. [Online] Available at: https://ssir.org/images/articles/2007SP_feature_martinosberg.pdf [Accessed 1 August 2020].

23.McMullen, J.S., \& Warnick, B. (2016). The downside of blended value and hybrid organizing. Journal of Management Studies, 53(4), 630-662. https://doi.org/10.5465/ambpp.2015.10130abstract.

24.Morris, M. H., \& Lewis, P.S. (1991). Entrepreneurship as a significant factor in societal quality of life. Journal of Business Research, 23(1), 21-36. https://doi.org/10.1016/0148-2963(91)90056-4.

25.Nicholls, A. (2008). Social Entrepreneurship: New Models of Sustainable Social Change. Oxford: Oxford University Press. 498p. Available at: https://global.oup.com/academic/product/social-entrepreneurship$9780199283880 ? \mathrm{cc}=\mathrm{us} \&$ lang=en\&.

26.OECD (2010). SMEs, Entrepreneurship and Innovation. [Online] Available at: http://rosted.nu/attachments/File/2010/SMEs_Entrepreneurship_and_Innovation_2010.pdf [Accessed 2 August 2020].

27.OECD (2020). Organisation for Economic Co-operation and Development - Better Life Index. [Online] Available at: http://www.oecdbetterlifeindex.org [Accessed 4 August 2020].

28.Owczarek, K. (2010). The concept of quality of life. Acta Neuropsychologica, 8(3), 207-213. Available at: https://www.researchgate.net/publication/289641702_The_concept_of_quality_of_life. 
29.Pathak, S., \& Muralidharan, E. (2018). Economic inequality and social entrepreneurship. Business \& Society, 57(6), 1150-1190. https://doi.org/10.1177/0007650317696069.

30.Phillips, W., Lee, H., Ghobadian, A., O’Regan, N., \& James, P. (2015). Social innovation and social entrepreneurship: A systematic review. Group \& Organization Management, 40(3), 428-461. https://doi.org/10.1177/1059601114560063.

31.Precupeţu, I., Mihalache, F., Petrescu, C., Pop, C. E., Tufă, L., \& Vasile, M. (2018). Quality of Life in Romania in the European Context. Bucharest: Quality of Life Research Institute. Available at: http://www.iccv.ro/wp-content/uploads/2018/03/Raport-Calitatea-Vietii.pdf.

32.Ratten, V., \& Welpe, I.M. (2011). Special issue: Community-based, social and societal entrepreneurship. Entrepreneurship \& Regional Development, 283-286. https://doi.org/10.1080/08985626.2011.580159.

33.Rey-Martí, A., Ribeiro-Soriano, D., \& Sánchez-García, J.L. (2016). Giving back to society: Job creation through social entrepreneurship. Journal of Business Research, 69(6), 2067-2072. https://doi.org/10.1016/j.jbusres.2015.12.010.

34.Santos, F.M. (2012). A positive theory of social entrepreneurship. Journal of Business Ethics, 111(3), 335-351. DOI:10.1007/s10551-012-1413-4.

35.Say, J.B. (1824). A Treatise on Political Economy (Translation). 4th ed. Massachusets: Wells and Lilly Press. Available https://books.google.bi/books?id=OcZBAQAAQBAJ\&printsec=frontcover\&hl=fr\&source=gbs ge sum mary $\mathrm{r} \& \mathrm{cad}=0 \# \mathrm{v}=$ onepage $\& \mathrm{q} \& \mathrm{f}=$ false.

36.Seelos, C., \& Mair, J. (2005). Social entrepreneurship: Creating new business models to serve the poor. Business Horizons, 48(3), 241-246. DOI:10.1016/j.bushor.2004.11.006.

37.Steyaert, C., \& Hjorth, D. (eds.) (2007). Entrepreneurship as Social Change. Cheltenham: Edward Elgar. 352p. Available at: https://research.cbs.dk/en/publications/entrepreneurship-as-social-change-a-third-newmovements-in-entrep.

38.Stiglitz, J.E., Sen, A., \& Fitoussi, J.P. (2009). The Measurement of Economic Performance and Social Progress Revisited. Paris: OFCE. [Online] Available at: https://hal-sciencespo.archives-ouvertes.fr/hal01069384/document [Accessed 29 July 2020].

39.Tan, W.L., Williams, J., \& Tan, T.M. (2005). Defining 'social' in social entrepreneurship: Altruism and entrepreneurship. International Entrepreneurship and Management Journal, 1, 353-365. DOI:10.1007/s11365-005-2600-x.

40.Toma, S.G., Grigore, A.M., \& Marinescu, P. (2014). Economic development and entrepreneurship. Procedia Economics and Finance, 8, 436-443. [Online] Available at: https://core.ac.uk/download/pdf/82660826.pdf [Accessed 29 July 2020].

41.TOMS Company (2006). About Toms. [Online] Available at: https://www.toms.com/about-toms [Accessed 30 July 2020].

42.TOMS Company (2019). Global Impact Report. [Online] Available at: https://media01.toms.com/static/www/images/landingpages/TOMS Impact/TOMS 2019 Global Impact Report.pdf [Accessed 28 July 2020].

43.United Nations (2015). Transforming our World: The 2030 Agenda for Sustainable Development. [Online] Available at: https://sustainabledevelopment.un.org/content/documents/21252030\%20Agenda\%20for\%20Sustainable \%20Development\%20web.pdf [Accessed 15 July 2020].

44.WHOQOL Group (1998). Development of the World Health Organization WHOQOL-BREF quality of life assessment. Psychological Medicine, 28, 551-558. Available at: https://depts.washington.edu/uwcssc/sites/default/files/hw00/d40/uwcssc/sites/default/files/WHO\%20Qua lity\%20of\%20Life\%20Scale\%20(WHOQOL).pdf.

45.World Health Organization (2020). Health statistics and information systems. [Online]. Available at: https://www.who.int/healthinfo/survey/whoqol-qualityoflife/en/. [Accessed 28 July 2020].

46.World Health Organization (2019). Drinking-water. [Online] Available at: www.who.int/news-room/factsheets/detail/drink-ing-water [Accessed 29 July 2020].

47.Zahra, S.A., Gedajlovic, E., Neubaum, D.O., \& Shulman, J.M. (2009). A typology of social entrepreneurs: Motives, search processes and ethical challenges. Journal of Business Venturing, 24(5), 519-532. https://doi.org/10.1016/j.jbusvent.2008.04.007.

48.Zahra, S.A., \& Wright, M. (2016). Understanding the social role of entrepreneurship. Journal of Management Studies, 53(4), 610-628. https://doi.org/10.1111/joms.12149. 